Article

\title{
Behavior of Human Bone Marrow-Derived Mesenchymal Stem Cells on Various Titanium-Based Coatings
}

\author{
Chengjuan $Q u^{1,2, *}$, Salla Kaitainen ${ }^{3}$, Heikki Kröger ${ }^{1}$, Reijo Lappalainen ${ }^{3}$ \\ and Mikko J. Lammi ${ }^{2,4, *}$ \\ 1 Department of Orthopaedics, Traumatology and Hand Surgery, Kuopio University Hospital, Kuopio 70210, \\ Finland; heikki.kroger@kuh.fi \\ 2 Department of Integrative Medical Biology, Umeå University, Umeå 90187, Sweden \\ 3 Department of Applied Physics, University of Eastern Finland, Kuopio 70211, Finland; \\ kaitaine@student.uef.fi (S.K.); reijo.lappalainen@uef.fi (R.L.) \\ 4 Key Laboratory of Trace Elements and Endemic Diseases, National Health and Family Planning Commission, \\ School of Public Health of Health Science Center, Xi'an Jiaotong University, Xi'an 710061, China \\ * Correspondence: chengjuan.qu@gmail.com (C.Q.); mikko.lammi@umu.se (M.J.L.); \\ Tel.: +358-44-363-2138 (C.Q.); +358-40-587-0601 (M.J.L.)
}

Academic Editor: Georgios E. Romanos

Received: 8 August 2016; Accepted: 6 October 2016; Published: 12 October 2016

\begin{abstract}
The chemical composition and texture of titanium coatings can influence the growth characteristics of the adhered cells. An enhanced proliferation of the human mesenchymal stem cells (hMSCs) would be beneficial. The present study was aimed to investigate whether titanium deposited at different atmospheres would affect the cell growth properties, cellular morphology, and expression of surface markers of hMSCs. Titanium-based coatings were deposited on silicon wafers under oxygen, nitrogen, or argon atmospheres by ultra-short pulsed laser deposition using two different gas pressures followed by heating at $400{ }^{\circ} \mathrm{C}$ for $2 \mathrm{~h}$. The characteristics of the coated surfaces were determined via contact angle, zeta potential, and scanning electron microscopy (SEM) techniques. Human MSCs were cultivated on differently coated silicon wafers for $48 \mathrm{~h}$. Subsequently, the cell proliferation rates were analyzed with an MTT assay. The phenotype of hMSCs was checked via immunocytochemical stainings of MSC-associated markers CD73, CD90, and CD105, and the adhesion, spreading, and morphology of hMSCs on coated materials via SEM. The cell proliferation rates of the hMSCs were similar on all coated silicon wafers. The hMSCs retained the MSC phenotype by expressing MSC-associated markers and fibroblast-like morphology with cellular projections. Furthermore, no significant differences could be found in the size of the cells when cultured on all various coated surfaces. In conclusion, despite certain differences in the contact angles and the zeta potentials of various titanium-based coatings, no single coating markedly improved the growth characteristics of hMSCs.
\end{abstract}

Keywords: human bone marrow-derived mesenchymal stem cells; ultra-short pulsed laser deposition; surface coating; cell culture; adhesion behavior

\section{Introduction}

The concept of tissue engineering has made great advances in the field of regenerative medicine, with the idea of using biomaterials and cells to construct new tissues to replace damaged ones in the body. The properties of human mesenchymal stem cells (hMSCs) provide potential for use in regenerative medicine as delivery vehicles for cell-based therapies [1]. They have been considered an alternative cell source for differentiated autologous chondrocytes due to their self-renewal and 
multipotent capacity to differentiate into different types of cells, including chondrocytes [2-6]. However, the quantity of hMSCs in bone marrow declines dramatically with age. It has been estimated that there is approximately one MSC per 10,000 cells in a newborn child's bone marrow, whereas a 50-year-old adult has one MSC per 400,000 cells, and an 80-year-old person has one MSC per 2 million cells [7]. Accordingly, it has been shown that the number of colony-forming units harvested per aspirate significantly decreased with age in women [8]. Importantly, the number of hMSCs needed in clinical experiments can be up to 24 million [9]. Thus, it can take a rather long time until enough cells in the monolayer expansion culture for the needs of clinical operations are obtained. Therefore, the enhanced rates of MSC growth in expansion cultures in vitro under environment, which maintain the MSC phenotype and differentiation capacity, would be beneficial for the purposes of tissue engineering.

Silicon has been widely used in biomedical applications [10-14]. It has been shown that the bioactive coating of silicon with bioactive molecules enhanced hMSC proliferation and retained the phenotype of MSCs, as well as the other types of cells [15-20]. Silicon substrates were shown to be a feasible novel cell culture material with good biocompatibility properties for myoblast cell adhesion and proliferation [19], and modified silicon has been widely used as a scaffold in cell-based therapy, tissue engineering, or both [15,21-23]. Silica nanoparticles have been shown to increase human adipose tissue-derived stem cell proliferation through ERK1/2 activation [24]. Various coatings on silicon wafers have also enhanced the proliferation of hMSCs compared with other types of cells, such as chondrocytes or osteoblasts [16].

Surface properties, such as topography, chemistry, stiffness, roughness, wettability, and energy, have been noted to influence the cell growth and differentiation capacity of stem cells $[25,26]$. Titanium (Ti) is often used to create artificial joints, pins, and other implants for orthopedic operations, since it does not irritate the human body and is shown to be biocompatible. Titanium dioxide $\left(\mathrm{TiO}_{2}\right)$-coated CoCrMo has improved the osteogenic differentiation and adhesion of hMSCs [27], and our previous study showed that $\mathrm{TiO}_{2}$ coating on cell culture dishes promoted hMSC proliferation without a loss in their chondrogenic differentiation capacity [28]. Cathodic arc plasma-treated Ti has been shown to enhance bone marrow MSC functions [29].

Oxygen and nitrogen are the main gases in the air. The surface coatings on materials are usually exposed to an atmospheric oxygen environment during coating processes or at least during application in cell cultures or as an implant. Ti especially is very reactive and forms at least a thin oxide layer on the surface. Argon is chemically very inactive and has been used to provide an inert atmosphere during deposition. It has been shown that argon protection could effectively reduce the air contaminants on acid-etched Ti implant surfaces and maintain the surface hydrophilicity and biological activity of implants [30,31], enhancing the early bone formation on Ti surfaces [30,32]. Nitrogen is a chemically neutral gas and does not change the biological properties of the samples. Therefore, in the present study, the Ti-based coatings were deposited on silicon or glass in oxygen, nitrogen, or argon atmospheres under two different gas pressures to study how the basic surface properties are affected. Then, the hMSCs were cultivated on these various coatings to investigate whether the different coatings with different surface properties on silicon would affect the proliferation, adhesion, and differentiation of the hMSCs. The main goal was to investigate whether it would be possible to find a coating that would provide the optimal proliferation of hMSCS without a loss in their cellular characteristics. An ultra-short pulsed laser deposition technique was used as a new technology, which allows for the production of well-controlled surface textures in different gas atmospheres.

\section{Materials and Methods}

\subsection{Materials}

Alpha-modified Eagle's medium ( $\alpha$-MEM), L-glutamine, fungizone, and penicillin/streptomycin were obtained from Euroclone (Pero, Italy), fetal bovine serum (FBS) from Hyclone (Thermo Scientific, 
Cramlington, UK), and TrypLE ${ }^{\mathrm{TM}}$ from Invitrogen (Carlsbad, CA, USA). Fibroblast growth factor-2 (FGF-2) and transforming growth factor $\beta_{3}\left(\mathrm{TGF}-\beta_{3}\right)$ were from Peprotech (London, UK). Toluidine blue was purchased from Serva (Heidelberg, Germany). In coating depositions, high-purity titanium (99.9\%) was from Koch-Light Laboratories Ltd. (Colnbrook, UK), and high purity oxygen, nitrogen, and argon were from AGA (HiQ Oxygen 6.0, HiQ Nitrogen 5.0, and HiQ Argon 6.0, Espoo, Finland). The antibodies against CD45 and CD105 were purchased from Development Studies Hybridoma Bank (Iowa City, IA, USA), those against CD73 and CD90 from Abcam (Cambridge, UK), and fluorescein isothiocyanate (FITC)-labeled secondary antibody from Chemicon (Temecula, CA, USA). For immunohistochemical stainings, an Envision+ System-HRP kit (Dako, Glostrup, Denmark) was used for detection. All the other chemicals were from Sigma-Aldrich (St. Louis, MO, USA).

The hMSC culture medium consisted of $\alpha$-MEM supplemented with $10 \%$ FBS, $100 \mathrm{U} / \mathrm{mL}$ of penicillin, $100 \mu \mathrm{g} / \mathrm{mL}$ of streptomycin, $2 \mathrm{mM}$ of L-glutamine, $50 \mu \mathrm{g} / \mathrm{mL}$ of 2-phospho-L-ascorbic acid trisodium salt, and $10 \mathrm{ng} / \mathrm{mL}$ of FGF-2. The chondrogenic medium contained serum-free $\alpha$-MEM supplemented with $10 \mathrm{ng} / \mathrm{mL}$ of TGF- $\beta_{3}$ (freshly added), $50 \mu \mathrm{g} / \mathrm{mL}$ of 2 -phosphos-L-ascorbic acid trisodium salt, $40 \mu \mathrm{g} / \mathrm{mL}$ of L-proline- $\mathrm{HCl}, 100 \mu \mathrm{g} / \mathrm{mL}$ of sodium pyruvate, $1 \%$ ITS +3 liquid media supplement, and $100 \mathrm{nM}$ of dexamethasone. The osteogenic medium consisted of $\alpha$-MEM supplemented with $10 \%$ FBS, $2 \mathrm{mM}$ of L-glutamine, $100 \mathrm{U} / \mathrm{mL}$ of penicillin, $100 \mu \mathrm{g} / \mathrm{mL}$ of streptomycin, $100 \mathrm{nM}$ of dexamethasone, $20 \mathrm{mM}$ of $\beta$-glycerophosphate, and $50 \mu \mathrm{g} / \mathrm{mL}$ of 2-phospho-L-ascorbic acid trisodium salt. The adipogenic medium consisted of $\alpha$-MEM supplemented with $10 \%$ FBS, $2 \mathrm{mM}$ of L-glutamine, $100 \mathrm{U} / \mathrm{mL}$ of penicillin, $100 \mu \mathrm{g} / \mathrm{mL}$ of streptomycin, $100 \mathrm{nM}$ of dexamethasone, $500 \mu \mathrm{M}$ of 3-isobutyl-1-methylxanthine, and $100 \mu \mathrm{M}$ of indomethacin. The control culture medium for the hMSCs was $10 \%$ FBS in $\alpha$-MEM supplemented with $100 \mathrm{U} / \mathrm{mL}$ of penicillin and $100 \mu \mathrm{g} / \mathrm{mL}$ of streptomycin.

\subsection{Sample Preparation}

High purity (100) silicon (Si-Mat, Landsberg am Lech, Germany) and glass microscope slides (Thermo Scientific, Menzel, Braunschweig, Germany) of a size of $76 \mathrm{~mm} \times 26 \mathrm{~mm} \times 0.8 \mathrm{~mm}$ were used as substrates. Thin films were deposited using the ultra-short pulsed laser deposition technique (USPLD). A total of six different sets were deposited, and for each set there were coated samples of both silicon and glass. First, the samples were loaded into a vacuum chamber. In vacuum, the sample surfaces were gently cleaned using HiQ Argon (AGA, Espoo, Finland) ion sputtering (SAM-7KV, Minsk, Belarus) before film deposition. For USPLD, we used a Tangerine fs fiber laser (Amplitude Systèmes, Pessac, France). The pulse length was $0.3 \mathrm{ps}$, with a pulse repetition rate of $2 \mathrm{MHz}$. Thin films were deposited in oxygen, nitrogen, and argon atmospheres using two different gas pressures-2 $2 \times 10^{-4}$ mbar or $2 \times 10^{-3}$ mbar. As a target, we used high purity titanium. After the depositions, the samples were heated at $400{ }^{\circ} \mathrm{C}$ for $2 \mathrm{~h}$ in the same atmosphere as that during the deposition. Subsequently, the samples were transitorily ultrasonicated in an ethanol-acetone solution (50:50 in volume).

\subsection{Contact Angle Measurements}

The sessile drop method was used to determine the contact angles of the different surfaces. A custom-made apparatus with a digital camera was used to take a photo of a 10- $\mu \mathrm{L}$ drop of deionized water on each surface. The contact angles were then measured with the GNU image manipulation program (GIMP, version 2.7.3, www.gimp.org). Mean values and standard deviations were then calculated.

\subsection{Zeta Potential Measurements}

The zeta potentials were measured using the electrokinetic analyzer (SurPass, Anton Paar GmbH, Graz, Austria) with the adjustable gap cell. We measured the zeta potentials from the coated and 
heat-treated silicon samples at a $\mathrm{pH}$ of about 7.0, according to the principles of the measurement previously described [28]. The electrokinetic analyzer's $\mathrm{pH}$ meter was used to monitor $\mathrm{pH}$.

\subsection{Cultivation of Human Mesenchymal Stem Cells (hMSCs)}

Human MSCs were isolated from bone marrow materials with permission from the North-Savo Health Care District Ethical Committee (license no. 62/2010), as described previously [28]. Human MSCs were cultured in the MSC culture medium in an incubator at $37^{\circ} \mathrm{C}$ with $20 \% \mathrm{O}_{2}$ tension and $5 \%$ $\mathrm{CO}_{2}$. When the cells reached $90 \%-95 \%$ confluency in the monolayer culture, they were harvested with trypLE, and 20,000 hMSCs were seeded in the MSC culture medium onto the coated silicon wafers or glass pieces, which were deposited in oxygen, nitrogen, or argon atmospheres from the Ti source. After the cells had been cultivated on various coated materials for $48 \mathrm{~h}$ at $37^{\circ} \mathrm{C}$, the samples were collected for MTT and immunocytochemical assays, and for scanning electron microscopic analyses.

\subsection{Characterization of Human Mesenchymal Stem Cells}

To ensure the mesenchymal characterization of the hMSCs from different donors used in this study, the expression of MSC-associated markers of CD73 (1:200), CD90 (1:200), and CD105 (1:200) were examined with an immunocytochemical assay as described in our previous study [33]. The functional characterization of hMSCs was performed using chondrogenic, osteogenic, and adipogenic differentiation assays of hMSCs as previously described [28,33].

The chondrogenic differentiation of hMSCs was performed in a pellet culture with 500,000 cells in the chondrogenic medium for 4 weeks. The osteogenic or adipogenic differentiation was carried out in a monolayer culture with 100,000 cells in the osteogenic or adipogenic medium for 4 weeks, respectively. The medium was changed three times per week during the culture period for all differentiation experiments. At the end of the differentiation periods, the cell pellets from chondrogenic differentiation were examined with histological stainings-for proteoglycans (PGs), with toluidine blue staining; for type II collagen, with immunohistochemistry [33,34]. The differentiated cells from osteogenesis and adipogenesis assays were visualized with stainings for alkaline phosphate (ALP) activity and Oil Red O (ORO), respectively $[33,34]$.

\subsection{Metabolic Activity Measurement}

The metabolic activities of the hMSCs cultured on various coated silicon samples were analyzed with an MTT colorimetric assay. After 48-h cultivation, the cells attached to the coated silicon wafers were carefully transferred to a new 24-well plate after washing with phosphate buffered saline (PBS), then $2 \mathrm{~mL}$ of a $0.5-\mathrm{mg} / \mathrm{mL}$ MTT reagent 3-(4,5-dimethylthiazol-2-yl)-2,5-diphenyltetrazolium bromide was added, and the cells were incubated at $37^{\circ} \mathrm{C}$ for $3 \mathrm{~h}$. Finally, the MTT formazan salt was dissolved in $1 \mathrm{~mL}$ of dimethylsulphoxide/ethanol $(1: 1, v / v)$, and the absorbances were measured at $595 \mathrm{~nm}$ with a 96-well plate reader. Three replicates for every sample were used in the measurement, and the experiment was repeated three times with three different donor cells.

\subsection{Immunocytochemical Analyses}

Immunocytochemical assays on silicon wafers were not successful. Therefore, the characteristic surface antigens of hMSCs were immunostained in cells adhered to the various glass coatings, manufactured in the same conditions as the coatings of silicon wafers. After 48-h cultivation, the cells attached to the coated glass samples were carefully transferred to a new 24-well plate after being washed with PBS; then, the cells were fixed with $4 \%$ paraformaldehyde. The fixed cells were further incubated with anti-CD73 (1:200), CD90 (1:200), CD105 (1:200), and CD45 (1:200) antibodies overnight at $4{ }^{\circ} \mathrm{C}$. On the next day, the cells were incubated with a secondary antibody (FITC-labeled goat anti-mouse, 1:200) for $1 \mathrm{~h}$ at room temperature in darkness. Finally, the cells were photographed with a fluorescence microscope after incubation with $1 \mu \mathrm{g} / \mathrm{mL}$ of 4'-6-diamidino-2-phenylindone for $15 \mathrm{~min}$ at $37^{\circ} \mathrm{C}[28,33]$. The experiment was individually repeated three times with three different donor cells. 
A 48-h culture time was chosen, since the surfaces were then rather confluent, and longer times were considered to have adverse effects on the cells. This time was thought to be long enough to observe whether loss in the hMSC-specific surface markers would appear.

\subsection{Scanning Electron Microscopic Analysis of Cell-Free Coated Materials and Cells}

Scanning electron microscopic imagings (SEM) and energy-dispersive $X$-ray spectroscopy (EDS) analysis of the coated surfaces were carried out using a Hitachi S-4800 FE-SEM (Hitachi Science System Ltd., Ibaraki, Japan) equipped with an EDS detector at an accelerating voltage of 5-10 kV.

After 48-h cell cultivation, the cells attached to the coated silicon samples were carefully transferred to a new 24-well plate after washings with PBS; then, the cells were fixed with $2.5 \%$ glutaraldehyde in a 0.1-mol/L sodium cacodylate buffer ( $\mathrm{pH} 7.4$ ) for $2 \mathrm{~h}$ at room temperature. The samples were further dehydrated with a series of gradually increasing concentrations of ethanol and hexamethyldisilazane. Finally, the samples were covered with gold by sputtering (AGAR auto sputter coater, Agar Scientific, Stansted, UK) for $20 \mathrm{~min}$ and monitored with the FE-SEM. The experiment was repeated three times with three different donor cells.

\subsection{Statistical Analysis}

A one-way ANOVA (IBM SPSS Statistics 21, New York, NY, USA) followed by the Bonferroni post-hoc test was used to check the statistical significance of the differences in cell proliferation between the different coated surfaces. The Kruskal-Wallis test was used to examine the statistically significant differences on the contact angle and zeta potential between the different coatings under the same gas pressure or different gas pressures in the same coatings. Significance level $p<0.05$ was considered statistically significant, and $p<0.01$ was considered as highly statistically significant.

\section{Results}

\subsection{Surface Characterization}

The contact angle is used to determine the wettability of a solid surface so that the larger the contact angle $\left(>90^{\circ}\right)$ is, the more hydrophobic the solid surface is. In this study, the contact angles of the coated silicon samples were $90^{\circ}$ or higher (Table 1). Significantly increased contact angles of coated silicon were achieved with a nitrogen atmosphere at a lower pressure, and with the presence of argon gas during the deposition (Table 1). The gas pressure had no significant effect on the contact angles of the coated silicon wafers under the oxygen and argon atmospheres at two different gas pressures (Table 1).

Table 1. The contact angles of the titanium-based coatings deposited on silicon. Oxygen, nitrogen, and argon gases were used during the depositions under the gas pressures of $2 \times 10^{-4}$ mbar and $2 \times 10^{-3}$ mbar.

\begin{tabular}{cccc}
\hline \multicolumn{4}{c}{ Ti-Based Coating on Silicon (Mean \pm S.D.) } \\
\hline Pressure (mbar) & Oxygen & Nitrogen & Argon \\
$2 \times 10^{-3}$ (higher) & $93 \pm 2$ & $87 \pm 3^{\mathrm{a}, \mathrm{b}}$ & $115 \pm 2$ \\
$2 \times 10^{-4}$ (lower) & $94 \pm 2$ & $118 \pm 3$ & $110 \pm 1$ \\
\hline
\end{tabular}

Statistical significances at $p$ value $<0.05$ : ${ }^{\text {a }}$ nitrogen-silicon at higher pressure vs. nitrogen-silicon at lower pressure; ${ }^{b}$ nitrogen-silicon at higher pressure vs. argon-silicon at higher pressure.

The zeta potential, an electrical surface property, depends on the properties of the material surface and the liquid on it. The higher the zeta potential is, the stronger the aggregative stability is, while a lower zeta potential means faster coagulation. In this study, the argon atmosphere at both gas pressures resulted in high negative zeta potential values, as well as coating under lower nitrogen atmospheres 
(Table 2), while zeta potentials were lowest in samples coated under the oxygen atmosphere (Table 2). The differences in $\mathrm{pH}$ values were small during the measurement (Table 2).

Table 2. Zeta potential (ZP) measurement of the coated silicon wafers. Oxygen, nitrogen, and argon gases were used during the depositions under gas pressures of $2 \times 10^{-4} \mathrm{mbar}$ and $2 \times 10^{-3} \mathrm{mbar}$.

\begin{tabular}{ccccccc}
\hline Pressure & \multicolumn{3}{c}{ Lower Pressure $\left(2 \times 10^{-4}\right)$} & \multicolumn{3}{c}{ Higher Pressure $\left(2 \times 10^{-3}\right)$} \\
\hline Atmosphere & Oxygen & Nitrogen & Argon & Oxygen & Nitrogen & Argon \\
\hline $\mathbf{Z P ~}(\mathbf{m V})$ & $-30.2 \pm 0.3$ & $-35.3 \pm 1.6$ & $-41.5 \pm 1.9^{\mathrm{a}, \mathrm{c}}$ & $-34.5 \pm 0.8$ & $-41.6 \pm 1.0^{\mathrm{b}, \mathrm{e}}$ & $-41.5 \pm 2.2^{\mathrm{d}}$ \\
\hline $\mathbf{p H}$ & $6.87 \pm 0.01$ & $7.01 \pm 0.01$ & $7.03 \pm 0.04$ & $6.97 \pm 0.04$ & $7.02 \pm 0.02$ & $7.13 \pm 0.04$ \\
\hline
\end{tabular}

Statistical significances at $p$ value $<0.01:^{a}$ argon at lower pressure vs. nitrogen at lower pressure; ${ }^{b}$ nitrogen at higher pressure vs. nitrogen at lower pressure; ${ }^{c}$ argon at lower pressure vs. oxygen at lower pressure; ${ }^{\mathrm{d}}$ argon at higher pressure vs. oxygen at higher pressure; ${ }^{e}$ nitrogen at higher pressure vs. oxygen at higher pressure.

Deposition under different conditions affected the surface roughnesses of the coatings on silicon wafers. Surfaces deposited under the higher pressure appeared to have slightly rougher surfaces than those deposited under the lower pressure (Figure 1). The size of the particles in the silicon material deposited in oxygen-plasma under the higher pressure appeared more uniform (Figure 1).

Higher pressure $\left(2 \times 10^{-3}\right)$
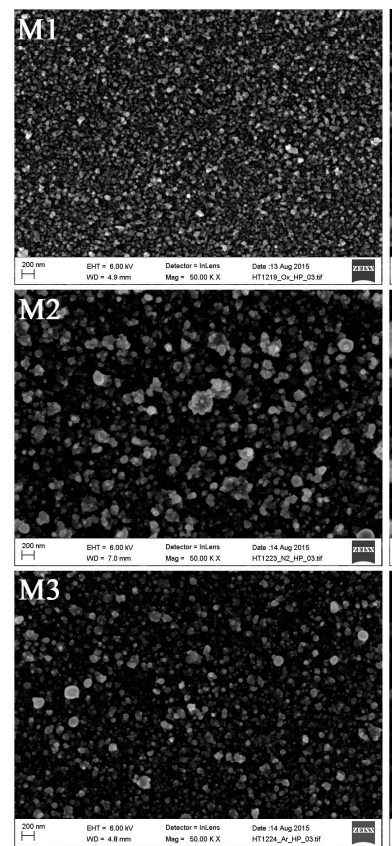
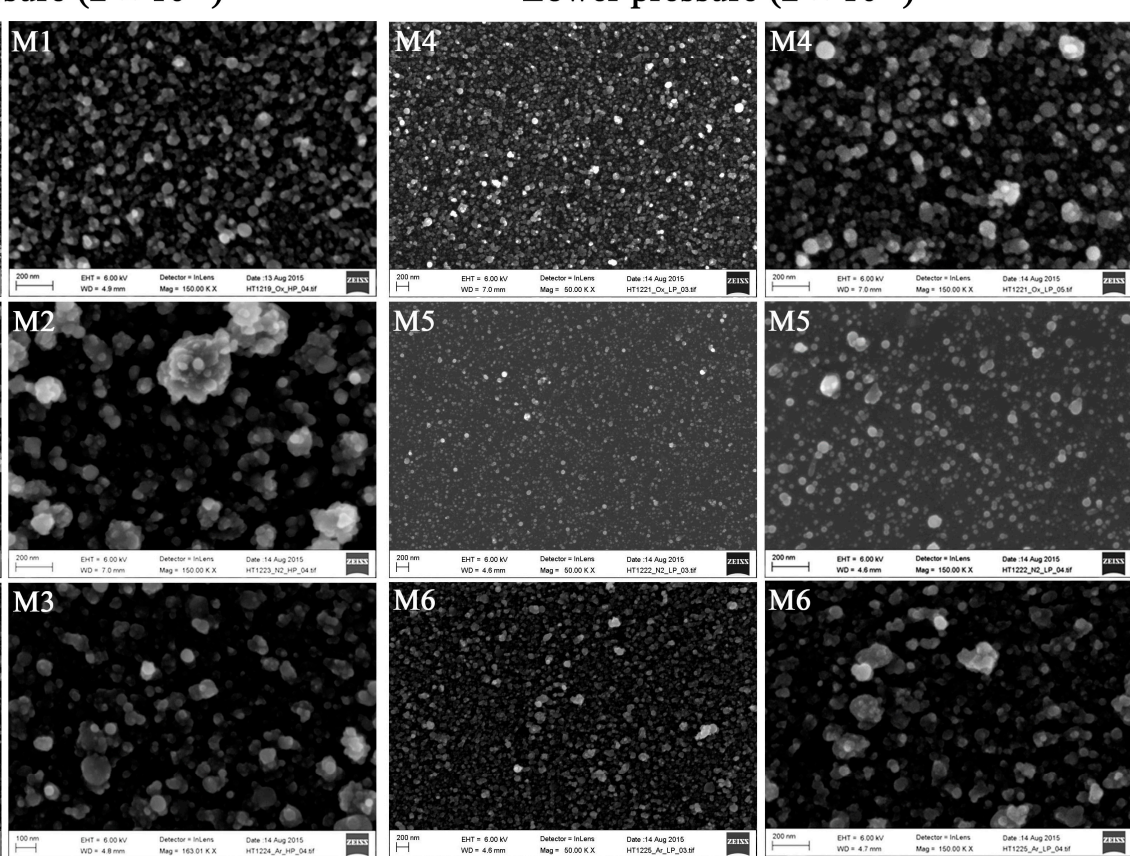

Figure 1. Scanning electron microscopic images of the cell-free surfaces of the titanium-based coatings deposited on silicon. Silicon wafers were coated under higher oxygen (M1, scale bar: left $200 \mathrm{~nm}$, right $200 \mathrm{~nm}$ ), nitrogen (M2, scale bar: left $200 \mathrm{~nm}$, right $200 \mathrm{~nm}$ ), and argon (M3, left $200 \mathrm{~nm}$, right $100 \mathrm{~nm}$ ) pressures and under lower oxygen (M4, scale bar: left $200 \mathrm{~nm}$, right $200 \mathrm{~nm}$ ), nitrogen (M5, scale bar: left 200 nm, right $200 \mathrm{~nm}$ ), and argon (M6, scale bar: left 200 nm, right $200 \mathrm{~nm}$ ) pressures.

\subsection{Characterization of the Used hMSCs}

The hMSCs used in this study were characterized by immunocytochemical stainings of MSC-associated markers-CD73, CD90, and CD105. All three donor hMSCs used in this study expressed surface markers CD73, CD90, and CD105 (Figure 2A), but did not express leukocyte marker CD45 (Figure 2A). The functional characterizations of hMSCs included chondrogenic, osteogenic, and adipogenic differentiation assays. After 4-week chondrogenic differentiation, the cell pellet was stained 
for PGs and type II collagen (Figure 2B). The osteogenically differentiated cells in the monolayer culture expressed alkaline phosphate activity (ALP) (Figure 2C), and the adipogenic differentiation produced cells that had a high degree of Oil Red O stained fatty droplets (ORO) (Figure 2C).

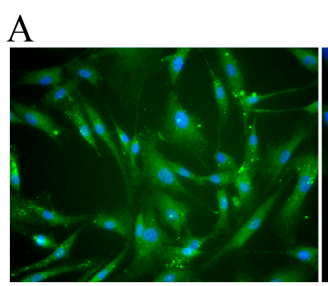

B

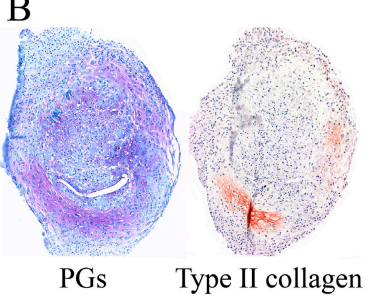

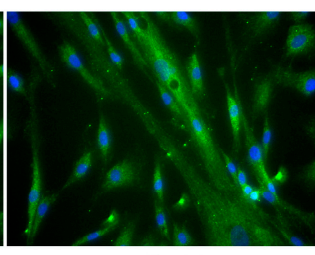

CD90

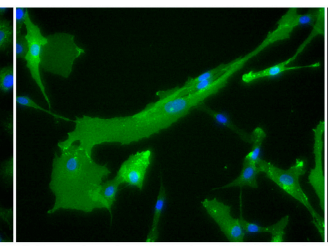

CD105

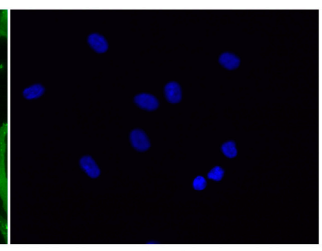

CD45

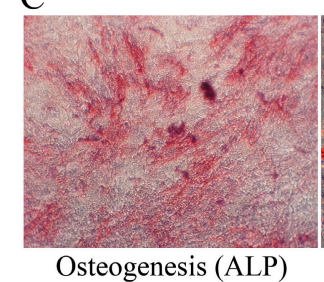

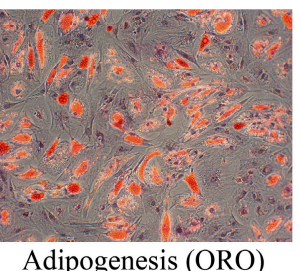

Figure 2. Representative images of characterizations of the human mesenchymal stem cells. (A) Immunocytochemical assays show that hMSCs expressed the known MSC-associated markers (CD73, CD90, and CD105), but not leukocyte marker CD45; (B) Chondrogenic cell pellets were positively stained with toluidine blue for PGs, and via immunohistochemistry for type II collagen; (C) Osteogenic cells in the monolayer culture were stained for alkaline phosphatase activity (ALP), and the adipogenic cells with Oil Red $\mathrm{O}(\mathrm{ORO})$ staining. The differentiation assays were performed separately for the cells collected from three different donors.

\subsection{The hMSC Morphology and Adhesion on Various Coated Silicon Samples}

The scanning electron microscopic analysis showed that the hMSCs displayed a fibroblast-like morphology (Figure 3) when the cells were cultivated on all various coated surfaces. The morphology of the hMSCs on various coated surfaces was similar to those cultured as a monolayer culture on standard polystyrene cell culture plates (Figure 3). The hMSCs grown on silicon wafers coated under a nitrogen atmosphere at the higher pressure appeared somewhat smaller in size than the cells grown on other coatings (M2, Figure 3). Therefore, image analysis of the cellular morphology was performed. The data of the cellular area and the perimeter gave some support for the assumption that the hMSCs cultured on the nitrogen-coated surface under high pressure were smallest in size. However, the differences were not statistically significant (Table 3). The circularity of the cells-a value of 1 representing a circular shape-remained almost constant at all coatings, varying in a range between 0.32 and 0.34 (Table 3). This indicates that the cells were mainly spindle-shaped. Solidity describes in geometrical terms the stiffness and deformability of an object. The higher the solidity is, the lower the cell deformability is. In the present study, the solidity values of the hMSCs cultured on various coated silicon samples were between 0.63 and 0.65 , and no statistically significant differences could be noticed within various coated silicon samples (Table 3 ). 
Table 3. The cell size and shape-associated parameters (mean \pm S.D.) of the human mesenchymal stem cells cultured on various coated silicon samples $(n=75)$. Oxygen, nitrogen, and argon gases were used during the depositions under gas pressures of $2 \times 10^{-3}$ (higher pressure) mbar and $2 \times 10^{-4}$ (lower pressure) mbar.

\begin{tabular}{ccccc}
\hline Materials & Cell Area $\left(\boldsymbol{\mu m}^{\mathbf{2}}\right)$ & Perimeter $(\mu \mathrm{m})$ & Circularity & Solidity \\
\hline M1 (Oxygen, higher pressure) & $2079.1 \pm 1374.8$ & $293.6 \pm 114.2$ & $0.32 \pm 0.14$ & $0.65 \pm 0.14$ \\
M2 (Nitrogen, higher pressure) & $2011.2 \pm 1331.0$ & $283.2 \pm 100.5$ & $0.33 \pm 0.16$ & $0.63 \pm 0.16$ \\
M3 (Argon, higher pressure) & $2352.7 \pm 1528.1$ & $311.0 \pm 133.7$ & $0.33 \pm 0.15$ & $0.63 \pm 0.17$ \\
M4 (Oxygen, lower pressure) & $2209.9 \pm 1649.5$ & $296.9 \pm 112.1$ & $0.32 \pm 0.12$ & $0.63 \pm 0.14$ \\
M5 (Nitrogen, lower pressure) & $2371.3 \pm 1620.6$ & $297.0 \pm 99.0$ & $0.34 \pm 0.16$ & $0.64 \pm 0.17$ \\
M6 (Argon, lower pressure) & $2195.3 \pm 1349.2$ & $309.8 \pm 110.8$ & $0.32 \pm 0.17$ & $0.65 \pm 0.17$ \\
\hline
\end{tabular}

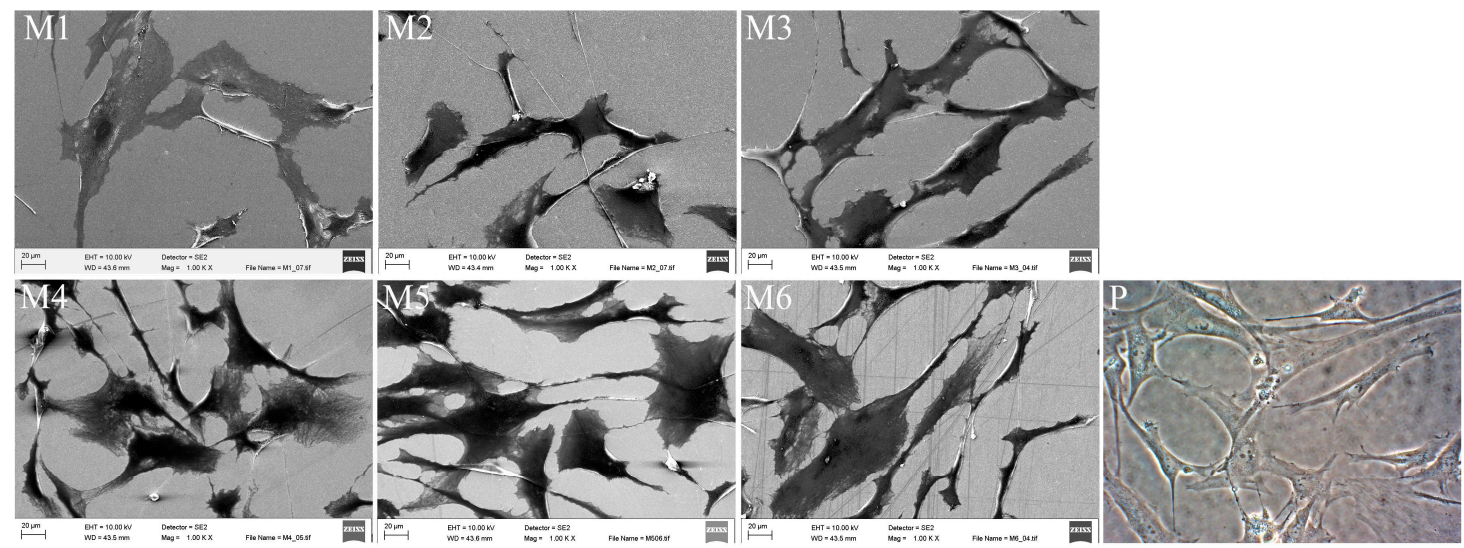

Figure 3. Representative of the morphology of the human mesenchymal stem cells after 48-h cultivation on various coated silicon samples and a polystyrene cell culture plate. Silicon wafers coated under higher oxygen (M1), nitrogen (M2), and argon (M3) pressures and under lower oxygen (M4), nitrogen (M5), and argon (M6) pressures. The scale bar represents $20 \mu \mathrm{m}$. (P) Shows cells on a polystyrene cell culture plate.

\subsection{The hMSC Proliferation on Various Coated Silicon Samples}

The MTT assay was used to analyze the cell proliferation when the hMSCs were cultivated on various coated silicon samples. The present results from three separate experiments showed no obvious differences in the cell number between any coated silicon samples after cultivation for $48 \mathrm{~h}$ (Figure 4 ).

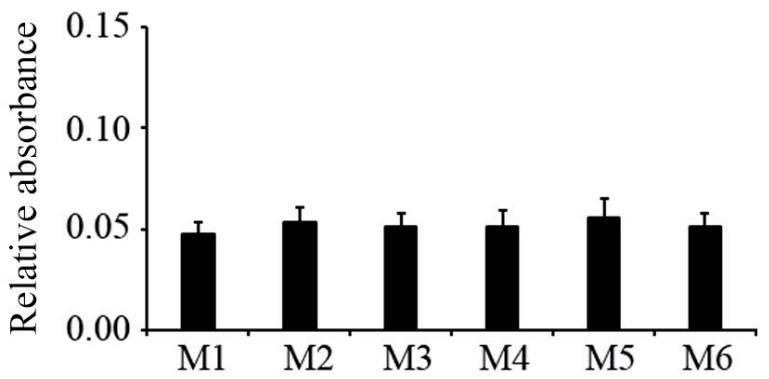

Figure 4. Cell proliferation assayed with MTT after 48-h cultivation of hMSCs on various coated silicon samples (mean \pm S.D., $n=3$ ). Silicon wafers coated under higher oxygen (M1), nitrogen (M2), and argon (M3) pressures and under lower oxygen (M4), nitrogen (M5), and argon (M6) pressures. 
3.5. The Expression of the hMSC-Associated Markers after hMSCs Were Cultivated on Various Coated Silicon Samples

The International Society for Cellular Therapy has stated that the hMSCs must express CD73, CD90, and CD105 and lack expression of CD45, CD34, CD14, or CD19 as the minimal criteria for defining multipotential MSCs [4]. In the present study, the hMSCs from three donors all expressed CD73, CD90, and CD105, but did not express CD45 (Figure 5). However, no noticeable differences could be seen in the expression of CD73, CD90, and CD105 when the cells were cultured on various coated samples (Figure 5).

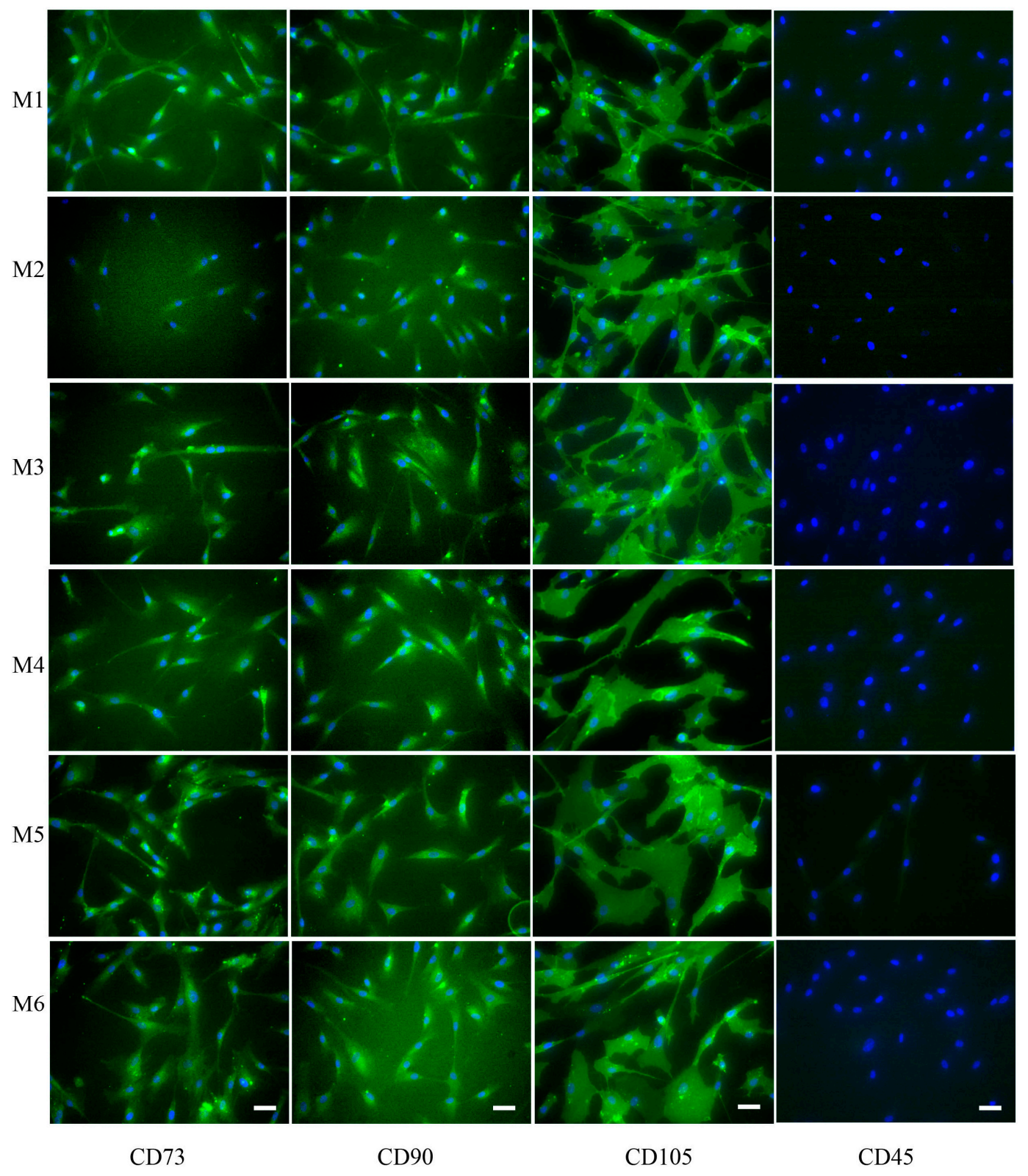

Figure 5. Representative of the immunocytochemical assay of hMSC-associated markers (CD73, CD90, and CD105), and CD45 after the cells were cultivated on various coated glass samples for $48 \mathrm{~h}$. Silicon wafers coated under higher oxygen (M1), nitrogen (M2), and argon (M3) pressures and under lower oxygen (M4), nitrogen (M5), and argon (M6) pressures. Scale bar is $25 \mu \mathrm{m}$. 


\section{Discussion}

The hMSCs have gained wide interest in cell-based tissue engineering of bone and articular cartilage, due to their multipotentiality to differentiate into osteoblasts and chondrocytes $[28,35]$. However, the large number of the chondrogenic hMSCs needed in the clinical application has also been noticed [9]. Our previous study showed that the proliferation rate of the hMSCs significantly increased when they were cultured on $\mathrm{TiO}_{2}$-coated cell culture dishes without loss of their capacity for chondrogenic differentiation [28]. Titanium and its alloys have been widely used as implant material in orthopedic application because of their desirable biocompatibility and bioactivity. Moreover, silicon possesses considerable potential in biochemical applications [19,36,37]. Therefore, in the present study, we investigated whether Ti-based coatings deposited in an oxygen, nitrogen, or argon atmosphere on silicon would be beneficial for the proliferation of the hMSCs. High speed ions of laser plasma plume effectively ionize gas atoms. Plasma treatments have been widely used in manufacturing surface modifications, which promote cell adhesion and proliferation [38].

In this study, the coatings with $\mathrm{Ti}$ were deposited under three different gas atmospheres, with the idea to investigate whether some coating conditions would yield surfaces optimal for the hMSC proliferation, yet maintain their expression of surface markers typical of hMSCs. The different coating conditions yielded surfaces, which had different characteristics of their contact angle or zeta potential, as well as their roughness. The hMSCs cultured on various Ti-based coatings on silicon wafers showed protrusions and firm adhesion on the coated surfaces. Coatings with $\mathrm{Ti}$ under lower nitrogen pressure produced the highest contact angle with relatively smooth surfaces. The cells appeared to be slightly smaller and had a relatively round shape on Ti-based coatings on silicon deposited under higher nitrogen pressure. Thus, the hydrophilicity of the materials obviously facilitates the cell adhesion and spreading [16,39]. Previously, it has been showed that a reduction of $80 \%$ in the cell adhesion was apparent when the contact angle was increased from $57^{\circ}$ to $122^{\circ}$ [40]. A hydrophilic polyurethane matrix promoted chondrogenesis of MSCs [41]. Superhydrophilic vertically aligned carbon nanotubes have permitted the adhesion and maintenance of human chondrocytes [42]. However, the results from our present study indicated that the proliferation of the hMSCs was not significantly different during the 48-h cultivation on various Ti-based coatings on silicon.

It has been shown that the surface roughness affected cell growth, adhesion, spreading, and cell functions [43-55]. Even though it has been shown that the cell adhesion or proliferation could be enhanced when the cells cultured on rougher surfaces $[43,46,49,51,55]$, the surface roughness could also reduce the cell adhesion, proliferation, or both $[47,53,55,56]$. Additionally, oxidized Ti samples with rougher surfaces improved the cell adhesion and osteogenic differentiation of the hMSCs [43]. However, no positive effects on the cell proliferation were observed [43]. The proliferation and differentiation of the cells derived from human mandibular bone was enhanced by the surface roughness of the Ti implant [44]. Our present results show that the variations in the surface properties affected by different sample production conditions did not remarkably change the investigated cellular properties, with the exception of a minor difference on the cell adhesion on Ti-based coating deposited in nitrogen under higher pressure compared with the others. This further confirmed our previous studies that the surface roughness did not significantly affect hMSC proliferation [16,26].

Gaseous plasma has been shown to improve biocompatibility by changing the chemical compositions and modifying the surface charge and roughness [57,58]. Oxygen, nitrogen, or argon, a variety of different plasma, can be applied for the surface modification. Oxygen is the most commonly used for plasma treatment of the surface to improve the wettability and controlling of the biocompatibility. It has been shown that the cell proliferation increased by $30 \%$ when HEMC- 1 cultured on oxygen plasma-treated polymers after $48 \mathrm{~h}$ [59]. Oxygen plasma-treated samples could enhance not only the cell adhesion and proliferation, but also the protein adhesion [38]. Nitrogen plasma treatment was more effective than argon and oxygen treatments in the modification of cyclic olefin copolymer microfluidic devices [60]. However, exposure to the air of argon plasma-treated surfaces leads to the 
incorporation of oxygen or nitrogen species [61-63]. Our present study showed that the hMSCs did retain the hMSC phenotype when cultured on Ti-based materials coated in oxygen, argon, or nitrogen, which further confirms our previous study performed with a $\mathrm{TiO}_{2}$-coated cell culture dish [28].

In conclusion, ultra-short pulsed laser deposition was used as a new technology for Ti-based surface coating deposition under various atmospheres. The present results indicated that the oxygen, nitrogen, or argon atmospheres on Ti-based coatings on silicon wafers produced surfaces, which were different in their surface characteristics but surprisingly appeared to be suitable for the hMSC cultivation and maintenance of their phenotype. Thus, none of the coatings was superior for providing an enhanced proliferation of hMSCs.

Acknowledgments: We would like to thank Henna Miettinen for her help with the order of the chemicals needed for the project. We express our special thanks to Virpi Miettinen, Jari Leskinen, and Arto P. Koistinen for their excellent professional assistance with the scanning electron microscope. We also thank the VTR project (5203089/titaanikantasolu/1V177) for supporting this study.

Author Contributions: C.Q., M.J.L., and R.L. conceived and designed the experiments; C.Q. and S.K. performed the experiments; C.Q. analyzed the data; H.K., M.J.L., and R.L. contributed reagents/materials/analysis tools; C.Q. and M.J.L. wrote the paper. All authors revised and proofed the paper before submission.

Conflicts of Interest: The authors declare no conflict of interest.

\section{References}

1. Chen, Y.; Shao, J.Z.; Xiang, L.X.; Dong, X.J.; Zhang, G.R. Mesenchymal stem cells: A promising candidate in regenerative medicine. Int. J. Biochem. Cell Biol. 2008, 40, 815-820. [CrossRef] [PubMed]

2. Vinatier, C.; Bouffi, C.; Merceron, C.; Gordeladze, J.; Brondello, J.M.; Jorgensen, C.; Weiss, P.; Guicheux, J.; Noel, D. Cartilage tissue engineering: Towards a biomaterial-assisted mesenchymal stem cell therapy. Curr. Stem Cell Res. Ther. 2009, 4, 318-329. [CrossRef] [PubMed]

3. Mobasheri, A.; Csaki, C.; Clutterbuck, A.L.; Rahmanzadeh, M.; Shakibaei, M. Mesenchymal stem cells in connective tissue engineering and regenerative medicine: Applications in cartilage repair and osteoarthritis therapy. Histol. Histopathol. 2009, 24, 347-366. [PubMed]

4. Dominici, M.; Le Blanc, K.; Mueller, I.; Slaper-Cortenbach, I.; Marini, F.; Krause, D.; Deans, R.; Keating, A.; Prockop, D.; Horwitz, E. Minimal criteria for defining multipotent mesenchymal stromal cells. The International Society for Cellular Therapy position statement. Cytotherapy 2006, 8, 315-317. [CrossRef] [PubMed]

5. Pittenger, M.F.; Mackay, A.M.; Beck, S.C.; Jaiswal, R.K.; Douglas, R.; Mosca, J.D.; Moorman, M.A.; Simonetti, D.W.; Craig, S.; Marshak, D.R. Multilineage potential of adult human mesenchymal stem cells. Science 1999, 284, 143-147. [CrossRef] [PubMed]

6. Caplan, A.I. Review: Mesenchymal stem cells: Cell-based reconstructive therapy in orthopedics. Tissue Eng. 2005, 11, 1198-1211. [CrossRef] [PubMed]

7. Caplan, A.I. Adult mesenchymal stem cells for tissue engineering versus regenerative medicine. J. Cell Physiol. 2007, 213, 341-347. [CrossRef] [PubMed]

8. Muschler, G.F.; Nitto, H.; Boehm, C.A.; Easley, K.A. Age- and gender-related changes in the cellularity of human bone marrow and the prevalence of osteoblastic progenitors. J. Orthop. Res. 2001, 19, 117-125. [CrossRef]

9. Emadedin, M.; Aghdami, N.; Taghiyar, L.; Fazeli, R.; Moghadasali, R.; Jahangir, S.; Farjad, R.; Baghaban Eslaminejad, M. Intra-articular injection of autologous mesenchymal stem cells in six patients with knee osteoarthritis. Arch. Iran. Med. 2012, 15, 422-428. [PubMed]

10. Desai, T.A.; Hansford, D.; Ferran, M. Characterization of micromachined silicon membranes for immunoisolation and bioseparation applications. J. Membr. Sci. 1999, 159, 221-231. [CrossRef]

11. He, W.; McConnell, G.C.; Bellamkonda, R.V. Nanoscale laminin coating modulates cortical scarring response around implanted silicon microelectrode arrays. J. Neural. Eng. 2006, 3, 316-326. [CrossRef] [PubMed]

12. Anglin, E.J.; Cheng, L.; Freeman, W.R.; Sailor, M.J. Porous silicon in drug delivery devices and materials. Adv. Drug Deliv. Rev. 2008, 60, 1266-1277. [CrossRef] [PubMed]

13. Chan, S.; Fauchet, P.M.; Li, Y.; Rothberg, L.J.; Miller, B.L. Porous silicon microcavities for biosensing applications. Phys. Status Solidi A 2000, 182, 541-546. [CrossRef] 
14. Dancil, K.S.; Greiner, D.P.; Sailor, M.J. A porous silicon optical biosensor: Detection of reversible binding of IgG to a protein A-modified surface. J. Am. Chem. Soc. 1999, 121, 7925-7930. [CrossRef]

15. Collart-Dutilleul, P.Y.; Secret, E.; Panayotov, I.; Deville de Periere, D.; Martin-Palma, R.J.; Torres-Costa, V.; Martin, M.; Gergely, C.; Durand, J.O.; Cunin, F.; et al. Adhesion and proliferation of human mesenchymal stem cells from dental pulp on porous silicon scaffolds. ACS Appl. Mat. Interfaces 2014, 6, 1719-1728. [CrossRef] [PubMed]

16. Lammi, M.J.; Qu, C.; Prittinen, J.; Koistinen, A.P.; Myllymaa, S.; Kröger, H.; Lappalainen, R. Adhesion and spreading of different skeletal cell types on variable surface coatings. In Proceedings of the 20125 th International Conference on Biomedical Engineering and Informatics, Chongqing, China, 16-18 October 2012; pp. 705-710.

17. Fan, Y.W.; Cui, F.Z.; Chen, L.N.; Zhai, Y.; Xu, Q.Y.; Lee, I.-S. Adhesion of neural cells on silicon wafer with nano-topographic surface. Appl. Surf. Sci. 2002, 187, 313-318. [CrossRef]

18. Maher, M.P.; Dvorak-Carbone, H.; Pine, J.; Wright, J.A.; Tai, Y.C. Microstructures for studies of cultured neural networks. Med. Biol. Eng. Comput. 1999, 37, 110-118. [CrossRef] [PubMed]

19. Bhuyan, M.K.; Rodriguez-Devora, J.I.; Fraser, K.; Tseng, T.L. Silicon substrate as a novel cell culture device for myoblast cells. J. Biomed. Sci. 2014, 21, 47. [CrossRef] [PubMed]

20. Martinoia, S.; Bove, M.; Tedesco, M.; Margesin, B.; Grattarola, M. A simple microfluidic system for patterning populations of neurons on silicon micromachined substrates. J. Neurosci. Meth. 1999, 87, 35-44. [CrossRef]

21. Hernandez-Montelongo, J.; Munoz-Noval, A.; Garcia-Ruiz, J.P.; Torres-Costa, V.; Martin-Palma, R.J.; Manso-Silvan, M. Nanostructured porous silicon: The winding road from photonics to cell scaffolds-A review. Front. Bioeng. Biotechnol. 2015, 3, 60. [CrossRef] [PubMed]

22. Lu, Y.; Yang, F.; Cai, L. Osteoblast adhesion on porous silicon. Bull. Adv. Technol. Res. 2009, 3, $25-28$.

23. Coffer, J.L.; Whitehead, M.A.; Nagesha, D.K.; Mukherjee, P.; Akkaraju, G.; Totolici, M.; Saffle, R.S.; Canham, L.T. Porous silicon-based scaffolds for tissue engineering and other biomedical applications. Phys. Status Solidi A 2005, 202, 1451-1455. [CrossRef]

24. Kim, K.J.; Joe, Y.A.; Kim, M.K.; Lee, S.J.; Ryu, Y.H.; Cho, D.W.; Rhie, J.W. Silica nanoparticles increase human adipose tissue-derived stem cell proliferation through ERK1/2 activation. Int. J. Nanomed. 2015, 10, 2261-2272. [CrossRef] [PubMed]

25. Myllymaa, S.; Kaivosoja, E.; Myllymaa, K.; Sillat, T.; Korhonen, H.; Lappalainen, R.; Konttinen, Y.T. Adhesion, spreading and osteogenic differentiation of mesenchymal stem cells cultured on micropatterned amorphous diamond, titanium, tantalum and chromium coatings on silicon. J. Mater. Sci. Mater. Med. 2010, 21, 329-341. [CrossRef] [PubMed]

26. Qu, C.; Myllymaa, S.; Prittinen, J.; Koistinen, A.P.; Lappalainen, R.; Lammi, M.J. Osteoblast behavior on various ultra-short pulsed laser deposited surface coatings. Mater. Sci. Eng. C Mater. Biol. Appl. 2013, 33, 1676-1682. [CrossRef] [PubMed]

27. Logan, N.; Sherif, A.; Cross, A.J.; Collins, S.N.; Traynor, A.; Bozec, L.; Parkin, I.P.; Brett, P. TiO 2 -coated CoCrMo: Improving the osteogenic differentiation and adhesion of mesenchymal stem cells in vitro. J. Biomed. Mater. Res. Part A 2015, 103, 1208-1217. [CrossRef] [PubMed]

28. Kaitainen, S.; Mahonen, A.J.; Lappalainen, R.; Kröger, H.; Lammi, M.J.; Qu, C. TiO 2 coating promotes human mesenchymal stem cell proliferation without the loss of their capacity for chondrogenic differentiation. Biofabrication 2013, 5, 025009. [CrossRef] [PubMed]

29. Zhu, W.; Teel, G.; O’Brien, C.M.; Zhuang, T.; Keidar, M.; Zhang, L.G. Enhanced human bone marrow mesenchymal stem cell functions on cathodic arc plasma-treated titanium. Int. J. Nanomed. 2015, 10, 7385-7396.

30. Zhao, Y.D.; Gao, Y.; Yue, J.; Ding, X.L.; Deng, Y.; Du, B.; Zhou, L. Effect of argon protection on the biological activity of acid etched titanium surface. Eur. Rev. Med. Pharmacol. Sci. 2015, 19, 1568-1576. [PubMed]

31. Giro, G.; Tovar, N.; Witek, L.; Marin, C.; Silva, N.R.; Bonfante, E.A.; Coelho, P.G. Osseointegration assessment of chairside argon-based nonthermal plasma-treated Ca-P coated dental implants. J. Biomed. Mater. Res. Part A 2013, 101, 98-103. [CrossRef] [PubMed]

32. Coelho, P.G.; Giro, G.; Teixeira, H.S.; Marin, C.; Witek, L.; Thompson, V.P.; Tovar, N.; Silva, N.R. Argon-based atmospheric pressure plasma enhances early bone response to rough titanium surfaces. J. Biomed. Mater. Res. Part A 2012, 100, 1901-1906. [CrossRef] [PubMed] 
33. Qu, C.; Rilla, K.; Tammi, R.; Tammi, M.; Kroger, H.; Lammi, M.J. Extensive CD44-dependent hyaluronan coats on human bone marrow-derived mesenchymal stem cells produced by hyaluronan synthases HAS1, HAS2 and HAS3. Int. J. Biochem. Cell Biol. 2014, 48, 45-54. [CrossRef] [PubMed]

34. Qu, C.; Puttonen, K.A.; Lindeberg, H.; Ruponen, M.; Hovatta, O.; Koistinaho, J.; Lammi, M.J. Chondrogenic differentiation of human pluripotent stem cells in chondrocyte co-culture. Int. J. Biochem. Cell Biol. 2013, 45, 1802-1812. [CrossRef] [PubMed]

35. Otto, W.R.; Rao, J. Tomorrow's skeleton staff: Mesenchymal stem cells and the repair of bone and cartilage. Cell Prolif. 2004, 37, 97-110. [CrossRef] [PubMed]

36. Formentin, P.; Alba, M.; Catalan, U.; Fernandez-Castillejo, S.; Pallares, J.; Sola, R.; Marsal, L.F. Effects of macro-versus nanoporous silicon substrates on human aortic endothelial cell behavior. Nanoscale Res. Lett. 2014, 9, 421. [CrossRef] [PubMed]

37. Torisawa, Y.S.; Shiku, H.; Yasukawa, T.; Nishizawa, M.; Matsue, T. Multi-channel 3-D cell culture device integrated on a silicon chip for anticancer drug sensitivity test. Biomaterials 2005, 26, 2165-2172. [CrossRef] [PubMed]

38. Recek, N.; Jaganjac, M.; Kolar, M.; Milkovic, L.; Mozetic, M.; Stana-Kleinschek, K.; Vesel, A. Protein adsorption on various plasma-treated polyethylene terephthalate substrates. Molecules 2013, 18, 12441-12463. [CrossRef] [PubMed]

39. Machado, M.M.; Lobo, A.O.; Marciano, F.R.; Corat, E.J.; Corat, M.A. Analysis of cellular adhesion on superhydrophobic and superhydrophilic vertically aligned carbon nanotube scaffolds. Mat. Sci. Eng. C Mater. Biol. Appl. 2015, 48, 365-371. [CrossRef] [PubMed]

40. Dowling, D.P.; Miller, I.S.; Ardhaoui, M.; Gallagher, W.M. Effect of surface wettability and topography on the adhesion of osteosarcoma cells on plasma-modified polystyrene. J. Biomater. Appl. 2011, 26, 327-347. [CrossRef] [PubMed]

41. Nalluri, S.M.; Krishnan, G.R.; Cheah, C.; Arzumand, A.; Yuan, Y.; Richardson, C.A.; Yang, S.; Sarkar, D. Hydrophilic polyurethane matrix promotes chondrogenesis of mesenchymal stem cells. Mater. Sci. Eng. C Mater. Biol. Appl. 2015, 54, 182-195. [CrossRef] [PubMed]

42. Antonioli, E.; Lobo, A.O.; Ferretti, M.; Cohen, M.; Marciano, F.R.; Corat, E.J.; Trava-Airoldi, V.J. An evaluation of chondrocyte morphology and gene expression on superhydrophilic vertically-aligned multi-walled carbon nanotube films. Mater. Sci. Eng. C Mater. Biol. Appl. 2013, 33, 641-647. [CrossRef] [PubMed]

43. Annunziata, M.; Oliva, A.; Buosciolo, A.; Giordano, M.; Guida, A.; Guida, L. Bone marrow mesenchymal stem cell response to nano-structured oxidized and turned titanium surfaces. Clin. Oral Implants Res. 2012, 23, 733-740. [CrossRef] [PubMed]

44. Mustafa, K.; Wennerberg, A.; Wroblewski, J.; Hultenby, K.; Lopez, B.S.; Arvidson, K. Determining optimal surface roughness of $\mathrm{TiO}_{2}$ blasted titanium implant material for attachment, proliferation and differentiation of cells derived from human mandibular alveolar bone. Clin. Oral Implants Res. 2001, 12, 515-525. [CrossRef] [PubMed]

45. Att, W.; Yamada, M.; Ogawa, T. Effect of titanium surface characteristics on the behavior and function of oral fibroblasts. Int. J. Oral Maxillofac. Implants 2009, 24, 419-431. [PubMed]

46. Osathanon, T.; Bespinyowong, K.; Arksornnukit, M.; Takahashi, H.; Pavasant, P. Human osteoblast-like cell spreading and proliferation on Ti-6Al-7Nb surfaces of varying roughness. J. Oral Sci. 2011, 53, 23-30. [CrossRef] [PubMed]

47. Solá-Ruiz, M.F.; Perez-Martinez, C.; Martin-del-Llano, J.J.; Carda-Batalla, C.; Labaig-Rueda, C. In vitro preliminary study of osteoblast response to surface roughness of titanium discs and topical application of melatonin. Med. Oral Patol. Oral Cir. Bucal. 2015, 20, e88-e93. [CrossRef] [PubMed]

48. Khan, S.P.; Auner, G.G.; Newaz, G.M. Influence of nanoscale surface roughness on neural cell attachment on silicon. Nanomedicine 2005, 1, 125-129. [CrossRef] [PubMed]

49. Zamani, F.; Amani-Tehran, M.; Latifi, M.; Shokrgozar, M.A. The influence of surface nanoroughness of electrospun PLGA nanofibrous scaffold on nerve cell adhesion and proliferation. J. Mater. Sci. Mater. Med. 2013, 24, 1551-1560. [CrossRef] [PubMed]

50. Balasundaram, G.; Storey, D.M.; Webster, T.J. Novel nano-rough polymers for cartilage tissue engineering. Int. J. Nanomed. 2014, 9, 1845-1853.

51. Da Silva, J.S.; Amico, S.C.; Rodrigues, A.O.; Barboza, C.A.; Alves, C.; Croci, A.T., Jr. Osteoblastlike cell adhesion on titanium surfaces modified by plasma nitriding. Int. J. Oral Maxillofac, Implants 2011, 26, $237-244$. 
52. Colombo, J.S.; Carley, A.; Fleming, G.J.; Crean, S.J.; Sloan, A.J.; Waddington, R.J. Osteogenic potential of bone marrow stromal cells on smooth, roughened, and tricalcium phosphate-modified titanium alloy surfaces. Int. J. Oral Maxillofac, Implants 2012, 27, 1029-1042.

53. Kuhn, S.; Kroth, J.; Ritz, U.; Hofmann, A.; Brendel, C.; Muller, L.P.; Forch, R.; Rommens, P.M. Reduced fibroblast adhesion and proliferation on plasma-modified titanium surfaces. J. Mater, Sci. Mater. Med. 2014, 25, 2549-2560. [CrossRef] [PubMed]

54. Zareidoost, A.; Yousefpour, M.; Ghaseme, B.; Amanzadeh, A. The relationship of surface roughness and cell response of chemical surface modification of titanium. J. Mater Sci. Mater. Med. 2012, 23, 1479-1488. [CrossRef] [PubMed]

55. Kunzler, T.P.; Drobek, T.; Schuler, M.; Spencer, N.D. Systematic study of osteoblast and fibroblast response to roughness by means of surface-morphology gradients. Biomaterials 2007, 28, 2175-2182. [CrossRef] [PubMed]

56. Rosa, A.; Beloti, M. Effect of cpTi surface roughness on human bone marrow cell attachment, proliferation, and differentiation. Braz. Dent. J. 2003, 14, 16-21. [CrossRef] [PubMed]

57. Ramires, P.A.; Mirenghi, L.; Romano, A.R.; Palumbo, F.; Nicolardi, G. Plasma-treated PET surfaces improve the biocompatibility of human endothelial cells. J. Biomed. Mater. Res. 2000, 51, 535-539. [CrossRef]

58. Van Kooten, T.G.; Spijker, H.T.; Busscher, H.J. Plasma-treated polystyrene surfaces: Model surfaces for studying cell-biomaterial interactions. Biomaterials 2004, 25, 1735-1747. [CrossRef] [PubMed]

59. Jaganjac, M.; Vesel, A.; Milkovic, L.; Recek, N.; Kolar, M.; Zarkovic, N.; Latiff, A.; Kleinschek, K.S.; Mozetic, M. Oxygen-rich coating promotes binding of proteins and endothelialization of polyethylene terephthalate polymers. J. Biomed. Mater. Res. Part A 2014, 102, 2305-2314. [CrossRef] [PubMed]

60. Roy, S.; Yue, C.Y. Surface modification of COC microfluric devices: A comparative study of nitrogen plasma treatment and its advantages over argon and oxygen plasma treatments. Plasma Proc. Polym. 2011, 8, 432-443. [CrossRef]

61. Suzuki, M.; Kishid, A.; Iwata, H.; Ikada, Y. Graft copolymerization of acrylamide onto a polyethylene surface pretreated with a glow dischargre. Macromolecules 1986, 19, 1804-1808. [CrossRef]

62. Johnsen, K.; Kirkhorn, K.; Olafsen, K.; Redford, K.; Stori, A. Modification of polyolefin surfaces by plasma-induced grafting. J. Appl. Polym. Sci. 1996, 59, 1651-1657. [CrossRef]

63. Øisetha, S.K.; Krozer, A.; Kasemo, B.; Lausmaa, J. Surface modification of spin-coated high-density polyethylene films by argon and oxygen glow discharge plasma treatments. Appl. Surf. Sci. 2002, 202, 92-103. [CrossRef]

(C) 2016 by the authors; licensee MDPI, Basel, Switzerland. This article is an open access article distributed under the terms and conditions of the Creative Commons Attribution (CC-BY) license (http:/ / creativecommons.org/licenses/by/4.0/). 